\title{
THE UNITED STATES-AUSTRALIA ALLIANCE IN THE POST-COLD WAR ERA AND ITS IMPACT ON SOUTHEAST ASIA
}

\author{
K. S. Balakrishnan
}

\begin{abstract}
Australia has been an ally of the United States (U.S.) for more than half a century. The Australian alliance with the U.S. began in 1951 with the signing of the Australia, New Zealand, United States (ANZUS)Pact. Since then Australia adopted a strategy of having military cooperation with both Britain and the U.S. The intensification of the Cold War in the 1950s onward in one way or another strengthened the U.S.-Australian alliance. Australia had significant access to intelligence, training and defence equipment supply from the U.S. Generally, the long period of the Cold War sustained the alliance and its implications on Southeast Asian security were regarded as overall positive. The end of the Cold War did not alter the U.S.-Australian alliance very much. In fact, there were more attempts to beef up defence cooperation between the two to check the rise of China. The two nations were fully aware that beefing up of the security cooperation is vital for long term peace in Southeast Asia and the Asia-Pacific in general. However, Australia no longer looks to embracing the U.S. in purely military terms. This article therefore argues that the impact of the U.S.-Australia alliance on Southeast Asia can no longer be seen in the way it was during the Cold War. The U.S.-Australia alliance also has strong tendencies to shape the character of region via regional architecture or institutions, including its political and economic direction. The alliance's impact on ensuring Southeast Asia remains within the circle of the West, and not China or Japan for that matter cannot be dismissed.
\end{abstract}

Keywords: alliance strategy, defence cooperation, security, Australia, United States, Southeast Asia, Asia-Pacific 


\section{INTRODUCTION}

The United States (U.S.) and Australia fought together during the Second World War. In many ways the presence of the U.S. troops in the South Pacific fighting the Japanese soldiers during the Second World War helped prevent Japan's advancement into Australian territory. The initial loss of Britain to Japan in Malaya and Singapore and its inability to defend Australia were clear signals for the government in Canberra to get closer to the U.S. on strategic military matters. Like the way it participated in Britain's war abroad during the colonial era, Australia became an ally of the U.S. and sent troops and fighter planes to wars in Korea and Vietnam during the Cold War. Even in recent years after the Cold War, Australia sent troops to Iraq and Afghanistan indicating strong support to the U.S. and President Bush's policy of the 'global war on terror'. During the Bill Clinton administration in 1998, Australia was planning to send troops to Iraq. During the 1991 Gulf War, Australia had also made significant contributions as an ally.

The alliance, which started as Australia, New Zealand, United States (ANZUS) in 1951, had indeed broadened its agenda and activities during the last half a century. While it can be regarded as a military alliance, the nature of the U.S.-Australia strategic alliance cannot be regarded as military alone. In fact, it is a large scale Western alliance that has the potential to shape vital agenda and the strategic direction in the Asia Pacific region. Its impact on Southeast Asia is manifold. The U.S.-Australia alliance is indeed dominant and can be perceived as hegemonic in many ways from the perspectives of the numerous smaller states in the region. While the benefits can be seen as positive on one side for the role in defence and security assistance that this platform provides, the U.S.-Australia alliance can be a problem for the Association of Southeast Asian Nations (ASEAN) countries in wanting to shape the direction of the region, the way the regional organization like ASEAN envisions. Sometime the plans of the U.S. and Australia contradict that of some ASEAN members, which prefer a non-aligned approach. This is evident in areas of strategic interest as well as in the economic realm, particularly on shaping regionalism. This study will trace the contribution the U.S.-Australia alliance during different phases of the Pacific century and its impact on Southeast Asia in the areas of regional security, politics and international economy. 


\section{THE U.S.-AUSTRALIA ALLIANCE: SERVING MUTUAL SECURITY INTERESTS}

During the Cold War the alliance with Australia served as a vital platform for the U.S. to spread its strength and influence in the region. The US was developing its military intelligence capability in Australia. The space-based facilities system and naval facilities in Australia helped the U.S. in gathering sufficient intelligence information on the USSR and other powers that were spreading their interests, not only in Southeast Asia but also up to the South Pacific region. The U.S. and Australia were clear about preventing the expansion of the communist powers. Indonesia, for example, had already a strong presence of the communist elements during the Sukarno era. As such, the fear of the effect of the domino theory becoming a reality loomed in the horizon. The fall of South Vietnam and later Cambodia to the strong control of the communist was the major concern, along with China's rising influence in the region. The U.S.-Australian alliance was vital for the Australian national security interests. Canberra's threat perception was all the way perceived coming from the northern region, which includes Southeast Asian neighbours. This has yet to change even today although the Cold War has ended. The only change that can be witnessed is that the concern is now over China rising, rather than Japan. The problem from Indonesia is more or less same, except there is more fear over terrorism, people smuggling and other human rights issues. The U.S.-Australian alliance was formidable during the Cold War, except for a request to revisit the treaty by some quarters in Australia in the late 1980s and with the end of the Cold War. Overall, it remains solid throughout the Cold War. The end of the Cold War has opened up new dimensions.

The debate on whether ANZUS can be still relevant became an important issue for Australia especially when there is rivalry between parties on foreign policy issues. New Zealand had a different policy direction and started looking skeptically at the alliance with the U.S. by the mid-90s. Wellington's threat assessment changed, as it no longer believed that the Union of the Soviet Socialists Republics (USSR) or other major Asian powers would have an interest to launch an attack on New Zealand. ${ }^{1}$ The cost of maintaining the alliance and better defence system can be also problematic for a small country like New Zealand. Generally, New Zealand depends on Australia for its security. 
In Australia, the debate on the alliance with the U.S. is unending when successive governments come into power. This trend could also be witnessed with the end of the Cold War. The Australian Labour Party normally prefers a balanced approach and has the tendency to be closer to Asia. The Liberal-Conservative government for the 12 years of the Howard era was extremely close with the U.S. and adopted a parallel policy approach with Washington in international arena on many serious issues be it on trade, regionalism, and climate change or on international security. ${ }^{2}$ This trend continues even today.

Influential Australian scholars too occasionally play a vital role in shaping the debate. With the end of the Cold War, one of the issues raised was on the U.S. military intelligence facilities in Australia. The U.S. military installation in Australia is always a subject very often discussed by the defence analyst and scholars in order to explain the strength of the ANZUS treaty during the Cold War although the alliance between the two states is beyond this. The nature of intelligence gathering activities is intense. It involves not only the U.S., but also Britain, Canada and New Zealand in an agreement that exist secretly beyond ANZUS. A study by Desmond Ball and Jeffrey T Richelson (1990) pointed out that signal intelligence is indeed the main activity involving some 418-signal intelligence stations of 322 operated by the U.S., 65 by Britain, 18 by Canada, 11 by Australia and two by New Zealand. The U.S. is noted to operate one of its stations from the Embassy in Canberra while Australia tends to have two stations in foreign embassies. In the first two decades of operation during the Cold War, Australia received some 94,000 reports from the U.S.' Central Intelligence Agency (CIA) and Britain's Secret Intelligence Service (SIS) while Canberra gave away some 10,000 reports of its own. ${ }^{3}$ Eminent Australian academics like Ball had revealed that the stations in North West Cape and Pine Gap could provide all necessary communications to U.S. military ships in the region. These satellite listening facilities are also well linked with the extensive airborne listening facilitated by the Airborne Warning and Control System (AWACS) operated by the U.S. ${ }^{4}$

One of the issues of great concern in the early 1990s was if the U.S. will be sharing the intelligence gathered with Israel. Australia has a foreign policy of staying neutral on the problem of Israel. There is a tendency among scholars to write and argue that it is highly possible 
for intelligence gathered using the facilities in Australia can be easily shared and could be helpful in enhancing the defence system of Israel. Generally, the intelligence and joint military facilities established under the auspices of ANZUS had a significant role in enhancing the U.S.Australia alliance beyond the Cold War. For example, although the Cold War had ended, not all of the bases and military communication facilities were closed down. The decision to fully hand over the U.S. naval communications station at North West Cape to Australia took place amidst the downscaling of bases abroad by Washington, in line with the policy to shut down bases in the Philippines at Subic naval and Clark air bases. But other intelligence facilities in Australia remain intact and were unaffected. In fact the scaling down and handing over of the facilities in North West Cape was not immediate but took several years after the Cold War. ${ }^{5}$

It is also important to point out that U.S.-Australia military alliance served the American interest not just for the surveillance of South and East Asia but one that of global significance. Australia participated either directly or indirectly in the attack on Iraq in January 1991 and also after March 2003. The intelligence facilities in Australia played a vital role for the U.S. security interest especially on missile defence and targeting. It can cover the Persian Gulf and the Indian Ocean. Linkages between the satellite communication facilities and U.S. warships in that zone were inevitable. Realizing the importance of these intelligence facilities in Australia to the United States global strategic plan and also the fact that Australia needed U.S. security assurance, the two governments had further plans to beef up their bilateral defence alliance in the wake other challenges in the form of scaling down of the U.S. forces and bases abroad by the mid-1990s. In fact, one could argue that incidents like that in Okinawa which angers the local Japanese who are against foreign bases can trigger the U.S. to upgrade its military alliance to a Western nation like Australia which has a long tradition of fighting wars together. So it is without doubt the U.S.-Australia alliance fits well in the context of the current Obama administration's U.S. Pivot or rebalancing strategy and policy.

The alliance with the U.S. has also served Australia's political interest. When the new Howard government came into power in early 1996, Canberra quickly altered the previous labor government's foreign policy of engagement with Asia by signing a new defence 
agreement with the U.S. in order to upgrade the level of military cooperation. The John Howard administration was generally critical of Paul Keating's policy of engagement with Asia by stating that Australia is a Western nation in terms of its identity. It did not support Keating's policy of Australia as part of Asia. By 27 July 1996, the Howard administration took advantage of the annual Australia-U.S. Ministerial Talk (AUSMIN) by signing a new defence agreement to upgrade military ties between the two governments, hence broadening further the kind of activities involving both the militaries. This resulted in the beginning of the large-scale military exercises like that of Tandem Thrust in northern state of Queensland involving some 22,000 forces. This large-scale training paved ways for a U.S. logistical support team to be stationed in Australia in between the military exercise. The agreement also allowed for the upgrading of the international spying station at the U.S. base in Pine Gap, near Alice Spring in central Australia. It also extended the lease till 2008 and the agreement to set up a new joint satellite early warning relay ground station in Australia for space based ballistic missile defence system. For Australia, the benefits were explained in the form of the continued supply of US military technology for defence of Australia. The U.S. on the other hand view Australia as a vital "southern anchor" of America's Asia Pacific security arrangements while having Japan as "northern anchor."

The joint military exercises between the U.S. and Australian forces eventually became the vital dimension of the ANZUS after the Cold War. This has been beefed up to another level after 11 September 2001. The series of military exercises have been more planned for enhancing communication, training and inter-operability. Generally, these exercises take place with an interest of protecting Australia from any danger of invasion from the North. Countries like Indonesia, Japan, India, China and Russia were regarded as potential adversaries to Australia security interest both during and after the Cold War. The threat from the North is viewed as a major source of security problem for Australia for many years now although Australia conducts many military exercises with Indonesia. The China threat is also very real for the Australian strategic planners. While this is debatable, the extent in which Australia worry about an invasion from the North is a serious one when one peruses its numerous defence policy documents. 
Politically, these issues can help the Defence Department in Australia to secure funding for its military.

Non-military threats in the form of refugees and smuggling have been also coming from the North through the Indonesian sea-lanes and the Indian Ocean. After the 11 September 2001 attack, the fear over rising terrorism forced the U.S. and Australia to engage on different form of military exercises, which also included anti-terror maneuvers at sea, and sharing of intelligence. Australia invoked the ANZUS Treaty after the attack on the World Trade Centre (WTC) in New York in order to provide troops, equipment and support for President Bush's Global War on Terror. ${ }^{7}$ It participated in the two major military campaigns in support of the U.S. in Afghanistan in October 2001 and the attack on Iraq in March 2003. Generally, the U.S. and Australia are engaged in a series of military exercises in recent decades. These include Exercise Tandem Thrust, Kingfisher and Crocodile series of joint exercises. At one time, some of the exercises can involve more than 20,000 military personnel.

In some instances, the other Western forces also joined this after 11 September 2001. For example, the Canadian forces participated in the Tandem Thrust exercise series in the year 2001. The Canadian Navy and Air Forces played the opposition role in that exercise, while the U.S. and Australian forces were playing the role of friendly forces. This was one of the largest exercises involving the Australian and the U.S. forces with the end of the Cold War in terms of number of the military personnel reaching some 27,000 . This was a massive amphibious exercise that combined both the sea, land and air elements. ${ }^{8}$ Another major combined exercise took place in 2005 codenamed as Talisman Saber at Shoalwater Bay Training Area, Townsville and the Coral Sea. This exercise involved crisis planning and contingency responses in the wake of Global War on Terrorism. It involved more than 6000 Australian and 11,000 U.S. military personnel from the navy, marine, land and air forces. Generally the exercise involved mock battle, amphibious operations, search and rescue operations and some community projects. ${ }^{9}$

Besides the joint military exercise, the ANZUS military alliance allows both the U.S. and Australia to engage in a series of high-level dialogues that are pertinent for addressing an array of security issues in 
the region. The focus of the AUSMIN and dialogues has been mainly on military security in the Asia-Pacific region. In addition to that, AUSMIN has also opened wide the subject of discussion to include human rights, democracy, drug, smuggling, environment, weapons of mass destruction (WMD) and terrorism. The series of dialogues and consultations at ministerial level has generally broadened the role of the alliance beyond the old ANZUS. ${ }^{10}$ Since 1996, discussion started even on tough issues like democracy in Myanmar; drug trafficking in Southeast Asia, the Korean Peninsula and suitability of trade liberalization using the Asia-Pacific Economic Cooperation (APEC) platform.

In fact, it is interesting to note that while the nature of the military alliance with U.S. was discussed on many occasions within the context of ANZUS in a traditional sense, the range of contacts, confidence and security building measures (CSBM) and strategic planning moved beyond purely intelligence sharing and military exercise. One could see how Canberra has been attempting to use the platform and meetings to participate actively in shaping the future direction of region in protecting the long-term Australian and Western interests. Therefore, one can no longer assume that U.S.-Australia military alliance as just for the purpose of forward defence and contingency planning the way it was during the Cold War. It is indeed an alliance that has a much bigger strategic agenda. To separate the military alliance as purely for military security reasoning is naïve and will be failure to assess Western agendas in the regional theatre. While this can be true, its military strategic value for both parties cannot be dismissed. The U.S.-Australia military exercise is still the largest in the region known as Talisman Sabre involving some 27,000 personnel, which will involve the US marines. In fact, Japan has shown interest for the first time in 2015 to participate with the U.S. marine by sending some 40 of its serviceman from the Japanese Ground Self-Defence Force. ${ }^{11}$

\section{THE U.S.-AUSTRALIA ALLIANCE AND ITS IMPACT ON SOUTHEAST ASIA: THE POLITICAL AND SECURITY DIMENSIONS}

The impact of U.S.-Australia alliance on Southeast Asia can be traced both historically and in current context. Historically, the effect of this strategic nexus could be witnessed with the way Australia contributed 
troops to the Vietnam War. During the late 70 s and early 80 s this relationship was manifested in Canberra's initiative of becoming an important player in absorbing the remnants of the security problems of the Indochinese states in the form of resettling the refugee problems. The U.S. and Australia had also played an important role in helping ASEAN to achieve stability in Cambodia by supporting its plan for a coalition government in that country. Australia too feels that it can play the role of a bridge between the U.S. or the West and Asia in order iron out differences and in serving the Western interest and its own national interest. One more important aspect that is worth mentioning is that both the U.S. and Australia provided ASEAN the necessary support in turning the regional organization into a viable entity by providing both monetary and training assistance, as well as the required political recognition. Both are vital dialogue partners of ASEAN for decades. Currently, both participate with ASEAN members in the East Asia Summit (EAS), APEC, ASEAN Regional Forum (ARF), ASEAN Defence Ministers Meeting Plus (ADMM Plus) and with some members in the Trans-Pacific Partnership Agreement (TPPA) dialogue.

During the Cold War era, many issues became problematic and the alliance provided the necessary support to ASEAN in addressing the problems in the region where both Australia and the U.S. helped addressed some of the pertinent issues directly threatening a few Southeast Asia states. After the Vietnam and Cambodian war, Australia provided some AU\$30 million and absorbed some 47,000 refugees by 1980 as part of the refugee resettlement program. ${ }^{12}$ Both the U.S. and Australia were fully aware that Southeast Asia must be engaged positively so that USSR and People's Republic of China (PRC) will not make the region a communist forte. During the mid-1950s, the U.S. was trying out establishing the Southeast Asian Treaty Organization (SEATO), which failed due to the lack of British support. But both the U.S. and Australia later pursued the struggle against the communist by promoting the interest of a non-communist regional organization like ASEAN.

The end of the Cold War generally brought about a different scenario with the collapsed of the USSR and its withdrawal from Vietnam much earlier. The Indochinese countries too, like China, began to embrace economic liberalization and saw the rise of 
capitalism in positive light. Some ASEAN countries, especially Malaysia began to state openly that the communist states like Russia, China and Vietnam were no longer a threat to regional security. As the Cambodian crisis ended in 1994, ASEAN by the mid-1990s worked actively to bring the Indochinese states into what was pronounced as a vision for One Southeast Asia. This vision was also propelled by a changing economic reality in the region. Between the late 1980s and the mid-1990s, several ASEAN countries enjoyed a spectacular economic growth. This changing strategic scenario brought a huge shift as the relationship between Vietnam and the U.S. improved in the 1990s. The perception of the communist threat became further remote. By 1995, Vietnam became an ASEAN member. Laos and Myanmar later followed this in 1997. Cambodia's membership was slightly delayed by ASEAN. It became a member only in 1999 after its internal political situation stabilized under Hun Sen. All the three Indochinese states and Myanmar had already signed the Treaty of Amity and Cooperation (TAC) by then expressing their interest in peaceful means of settling disputes and becoming a part of the regional vision of 'One Southeast Asia'. By 1993, the U.S. had withdrawn its forces permanently from the Subic and Clark bases in the Philippines. This is in a way made ASEAN more credible by making the region appearing more neutral in the eyes of Russia and China, in line with the Zone of Peace, Freedom and Neutrality (ZOPFAN) declaration.

Overall, these strategic shifts had a positive impact on the U.S.Australia alliance. Both Australia and the U.S. had to device new approaches to engage the region. The two had long realized the fact that engaging Southeast Asia via the military means alone would not be strategically wise. The end of the Cold War provided the necessary environment to look at alternative approaches. The two realized the importance of having a security dialogue initiative for the region. There were some discussions about the creation of an European-type of CSBM initiative. But ASEAN was against this, citing reason that the regional architecture must be different from that of Europe as the security situation of Asia is not the same. This eventually resulted in ASEAN agreeing in a post-Ministerial Meeting to set up the ARF as a dialogue platform for regional security for Southeast Asia and the wider Asia-Pacific. The ARF since then is a co-chaired body between an ASEAN member and non-ASEAN states of the Asia-Pacific region. Both the U.S. and Australia are active members in some of the Inter- 
Sessional Meetings and other Study Groups initiated under ARF. Besides ARF, both the U.S. and Australia along with the ASEAN members are also active in the Council for Security Cooperation in the Asia Pacific (CSCAP) and its related working groups that provide policy inputs to ARF. ${ }^{13}$ Among the issues focused include confidence building measures, military cooperation, concepts of security, transnational crime, terrorism, the Korean Peninsula, maritime security, nuclear proliferation and several other non-traditional security issues. Interestingly, these issues similarly appear as vital agenda in the U.S.-Australia AUSMIN dialogues too.

While both the U.S. and Australia participate as independent sovereign states in ARF, the support the two provides for the security projects in the form of working groups and conceptual papers are generally significant. The impact on shaping security agenda cannot be dismissed. The ASEAN countries are in many ways on the receiving side on many of the security agenda because of its lack in terms of the military instruments, advance space based intelligence system and defence funding for cooperation. The attack on 11 September 2001, took security cooperation to greater heights. Incidents like the Bali bombings, the bombing of Australian Embassy in Jakarta and the attack on the Marriott Hotel, further enhanced cooperation to face the common enemies. Intelligence sharing too became more pertinent. Although fighting terrorism is a common goal for all affected countries in the region, the manner in which the U.S. and Australia go about doing this is different. The Southeast Asian states too had rich experiences of combating terrorism prior to 11 September in their own way.

But both Australia and the U.S. have never consulted ASEAN deeply on these approaches. The two prefer the hard approaches by using a lot more of the military and intelligence means as modus operandi. Both the U.S. and Australia appeared as pressuring ASEAN countries to do more after 11 September 2001. When it comes to other form of assistance like funding and equipment in certain zone, it is of no avail to ASEAN's expectation. Strong allies like the Philippines may have benefited more than the others. It is different with Japan, which provided ships and funding assistance for the safety of navigation in the Straits of Malacca and appeared quite responsible. The U.S. prefers to provide assistance to combat terrorism in the Southern Philippines 
but was slow in providing the kind of support needed for Indonesia. Indonesian human rights record and independent foreign policy could be a reason for such delays in providing assistance. It is different with the Philippines because of the existence of the security agreement and the long-term strategic interest of the two players.

Some ASEAN states, especially the littoral states of the Strait of Malacca were also pressured to accept the modus operandi of the U.S. and Australia. Following the pressure after 11 September, the ASEAN states had to express their differences on the policy initiative like the Regional Maritime Security Initiative (RMSI) pursued by the U.S. because of its potential to impinge on national sovereignty. The littoral states of the Strait of Malacca were indirectly pressured to create the 'Eye in the Sky' surveillance initiative on their own and keep active cooperation in and around the Strait of Malacca. This is one way in which the littoral states of the Strait of Malacca were trying to maintain sovereignty in their maritime territory. Malaysia and Indonesia were uncomfortable with the U.S. demands. The two felt that the Malacca Strait had no track record of terror attacks and too much publicity is bad for the strait. Beside the RMSI, Port Security Initiative (PSI) became another initiative forced upon the ASEAN members. Generally, the regional countries had no choice but succumb to this type of pressure and initiatives because of their long term commercial interest with the U.S. Australia too was trying to emulate the U.S. by declaring the 1,000 kilometre maritime security zone expecting ASEAN countries would allow ships to be inspected prior to arriving in Australia. ${ }^{14}$

Prime Minister John Howard went to an extent of saying Australia may use pre-emptive strike in the region if necessary, more or less emulating the Bush administration's policy of pre-emption. It was criticized by leaders like Mahathir who rebuked Australia as being the U.S. lackey and acting like a Deputy Sherriff in the region. While ASEAN was generally supportive of the West in security arrangements for combating terrorism, it was not happy about the aggressive ways of the U.S. global and regional role, including the support from Australia for Washington. The approaches of ASEAN are slightly different than the U.S. and Australia. ASEAN prefers both the hard and soft approaches in combatting terrorism, whereas the US was more focused on hard approaches during the last several years. Some of the members in ASEAN were not happy about the war 
in Iraq too. These members regard the U.S., Britain and Australia's involvement in the war in Iraq will not solve the problems of global terrorism. It is indeed very obvious that Canberra's policy has been very much influenced by the decisions in Washington. This may not be respected by all the ASEAN states. States with significant Muslim population like Indonesia and Malaysia are generally against the idea of attacking another Muslim state.

In fact, there were no positive statements from any of the ASEAN leaders supporting the war in Iraq in 2003 and also the attack on Afghanistan in 2002. Close to 40 percent of the population in the Southeast Asian states are Muslims. The other ASEAN leaders too were careful when making statements on the U.S. war in Iraq and Afghanistan fearing repercussion or resentments from the local Muslim organizations and separatists elements. It is indeed difficult to erase the general discomfort and negative feeling that the global war on terror led by the US and its allies. In fact, the attack on Afghanistan and Iraq had only increased terrorism in Southeast Asia after 11 September 2001. This was later followed by travel warning to the U.S. and Australian citizens to the affected countries like Indonesia and Thailand. Malaysia leaders, for example, were not happy about these travel warnings because of its adverse economic impact and the potential implications on incoming investments.

The Obama administration is currently trying to undo the past and alter this image problem created by the Bush administration via the global war on terror. His government is attempting to come out of Iraq as quickly as possible, and also by telling the Muslim world that the U.S. is not perfect and willing to work towards a perpetual peace. President Obama has gone as far as stating that his administration does not believe in imposing democratic changes without the approval of the people in other regions. He also said recently that the U.S. would not impose any kind of government on another country while having the belief in democratic values. ${ }^{15}$ His administration had signed the TAC in July 2009, which definitely pleases ASEAN after a long wait. Australia signed the treaty in 2005 in order to secure a seat in the EAS held in Kuala Lumpur that year. Initially, the Howard administration was ambivalent in its position to sign the treaty between 2000 and 2005. These steps were vital in fostering good relationship with the region. 
The promotion of human rights and democracy is another important concern in understanding the political and security impact of the U.S.-Australia alliance in regional affairs both in the South Pacific and in Southeast Asia. The impact on Southeast Asia stems from a political difference over issues pertaining to democracy and human rights. With end of the Cold War and the Tiananmen tragedy in 1989, the U.S., Australia and European allies were frequently raising the issues of human rights and democracy in numerous international forums. Being a close ally of the U.S. and of the West, Australia became an important player in the region that behaves in a certain way raising these issues with regional countries. In Washington, the Clinton administration was also voicing on linking trade and aid with human rights issue during the early 90s. Although Australia is a much smaller power compared with the U.S., Canberra began to take the agenda seriously and interfered in regional affairs in the name of promoting human rights and democracy. Countries like Malaysia regards Australia fond of lecturing the region on human rights without taking into consideration of its government's long historical record of abusing the rights of its own aboriginal community and also the prevalence of racism at the local level. The rise of far right political leaders like Pauline Hanson who called for reducing the intake of Asian immigrants in Australia is a good example, which provides the ground for the existence of racism in that country. Numerous other overseas student incidents can be also traced back to racism including the one involving Indian students' massive demonstration in Australia against racism and discrimination in 2009. Numerous surveys have generally indicated the prevalence of racism. While Australia's own record on human rights is not commendable, it is known for interfering in regional affairs on issues directly related to human rights and democracy. The U.S. too has its own share of racism issues and image damaging records on human rights issues like the Guantanamo prisoners' case and the U.S. adventure into Iraq and Afghanistan.

Australia's meddling in internal affairs of countries like Fiji, Malaysia, Solomon Islands, and Papua New Guinea can be sometime problematic and disliked by most countries in Southeast Asia. There is a tendency from Australian leaders and opposition politicians passing remarks on regional countries on the status of democracy and human rights without taking into account the historical realities of nation building in region, which involved colonial constructs. Australian 
media too had been very critical and portrayed negative images of politics and leadership in these countries more often negative than the positive happenings in the region. While not all the cases can be directly attributed to the role played by the U.S.-Australia alliance, its potential in influencing certain type of military interference in the name of human rights cannot be dismissed. Without the support from the U.S., Australia may not be really behaving the way it has been in certain issues.

Australia's role in East Timor (Timor Leste) is a classic case. Australia had for many years accepted that East Timor was a part of Indonesia. But when the crisis in East Timor got worse in 1999, the Howard administration took advantage of it during Clinton's visit to New Zealand for the APEC summit in 1999 and also the World Trade Organization (WTO) Summit in Seattle in the same year to ensure that the East Timor agenda is brought into discussion in forums so that the issue get sufficient attention and Washington would approve Australia's leadership in managing the crisis. Clinton administration was not very highly supportive of Australia's leadership role in East Timor. This later resulted in the International Force for East Timor (INTERFET) being changed to the United Nations Transitional Administration in East Timor (UNTAET) which started the rotational command for the forces and provided the United Nations face for the mission so that views and role of other regional countries were considered. ${ }^{16}$ This issue revealed that while the U.S. had supported the Australian role in East Timor, it did not highly encourage Australian leadership during the Howard administration. The media too had generally painted Australia was trying to behave like a "deputy sheriff" by misquoting John Howard which he was unable to correct such claims given his unequivocal support to the U.S. Overall, the global media too was very critical of Australia's peacekeeping role in East Timor although it could be regarded a successful mission for Canberra. Australia is also known as exploitative of smaller countries in the South Pacific. The oil joint-exploration or the Timor Gap treaty with East Timor is a good example where Timorese felt they didn't get a good deal compared with Australian companies when come to areas of exploration.

Malaysia-Australia rivalry for influence in the South Pacific warrants a separate article altogether. Australia too is very highly concerned of China's future role in East Timor and in the South 
Pacific. Although Australian Prime Minister Kevin Rudd started well his leadership in praising Asia and China, but in recent months he too is saying that China can be a problem. One of the main reasons to increasing Australia's military spending in 2009 by his administration is the concern over China. China's bourgeoning defence spending in recent decades and military modernization is a major concern for Australia. China threat has always preoccupied the mind of the leaders in Washington occasionally. Australia is one nation in Asia that echoes the issue of the China threat. This is expressed often among successive Australian leaders either publicly or in private. Australia has a record on spying over China's embassy in Canberra. A Chinese diplomat had been also accused of doing the same in the past. In July 2009, China had detained four officers of an Australian corporation, Rio Tinto on the ground of engaging in commercial espionage. ${ }^{17}$ Although the issue is not directly impacting on Southeast Asia, it is important to note that Australia's role in amplifying China threat or the Japanese threat during the Cold War has yet to fade. While Japan receives a more favorable image, China is projected as a serious threat, which can influence defence spending in the region. Singapore and Malaysia are also members in Five Power Defence Arrangement (FPDA) of which Australia is a major player. Australia and the US policies and threat perception influence several Southeast Asian countries on regional security.

In fact, given the issue of rising new threats after the Cold War, Australia signed a security agreement with Indonesia during the Keating era in 1995 and at the same time the involvement in the FPDA exercises and intelligence sharing with Malaysia and Singapore for several decades now boosts Canberra's role in influencing regional security agenda in Asia. The U.S. too is actively engaging on intelligence gathering activities in numerous ways that focus on China and Southeast Asia. The Obama administration's U.S. Pivot is a huge example that supports developments in the region. The impact of this sort of an alliance in shaping the agenda on whom and what is a future threat to the region is consistent. There is also other larger agendas for both the U.S. and Australia, especially is ensuring that the new and rising economies of Southeast Asia remain within the Western ambit. This will ensure that future weapons procurement of the Southeast Asian countries do not change direction but remain within the alliance framework. Although this is not done as a bilateral 
consortium, both Australia and the U.S. generally sent teams to bid for defence contracts and tenders.

The fact that both the U.S. and Australia are influential in shaping the direction of strategic thinking; defence policy and planning in Southeast Asia can be also obvious. This is not only taking place when top U.S. and Australian officials are sent to the region to explain policy positions and networking for future initiatives, but the influences can be even more dominant at the level of track two security policy dialogues and meetings. Both Australia and the U.S. are vital players on track two organizations like the CSCAP, which serves in advisory capacity on policy issues for the ARF. ${ }^{18}$ Organization like CSCAP produces numerous policy papers, newsletters, reports and documents. The chances of these policy papers and reports being used by the officials in the region are high indeed. Governments in Southeast Asia are sending officials to attend the annual conferences and working group meetings more regularly in recent decades. The ARF-CSCAP collaborations at the working group level are quite visible. There is a greater understanding among the policy officials in the region at least at the conceptual level of various policies. The culture of transparency on security and defence matters is definitely on the increase. The role played by the U.S. and Australia in developing this sort of strategic culture in Southeast Asia is commendable.

At another deeper level, countries like Malaysia, Indonesia, Singapore, Thailand, Brunei and Philippines are already benefiting from the U.S. support in defence training assistance. The aftermath of 11 September 2001 had without doubt increased the possibility for military and security official exchanges. Intelligence sharing is currently at the highest level among the ASEAN members, Australia and the United States. Canberra had signed several memorandum of understanding $(\mathrm{MoU})$ on countering terrorism with ASEAN states. The U.S. plan for the extension of National Missile Defense (NMD) plan into what is regarded as theatre missile defense (TMD) plan covering Asia is another obvious project that naturally involves Australia given the location of vital satellite and intelligence facilities there.

The impact of this military project shaping the future strategic direction of Southeast Asia and Asia in general is highly visible on many security issues affecting the region. This is because the problems 
of the Korean Peninsula and also the Cross Strait tensions between Taiwan and China can no longer be seen in isolation given the maritime nature of the conflict because of sea-lanes. For some smaller ASEAN countries, the prosperity of the region is highly dependent of the long term U.S. security assurance in the regional maritime zone. While these countries are comfortable with a prosperous China, the fear over China's military activities in the South China Sea is unending. Many maritime disputes in Southeast Asia remain unresolved and China's is not an easy party to deal with on those issues given her historical claims of the South China Sea. The progress of signing a 'Code of Conduct' with China is not all that simple. Similarly, China is also wary of the military development in Taiwan, Japan and the presence of the U.S. Pacific Fleet. In response, the PRC is spending more to upgrade its military. Its aircraft carrier is already on operational test mission.

In sum, these geo-strategic scenarios make the U.S.-Australia alliance being occasionally viewed positively in some ASEAN capitals. However, events like 11 September 2001 and several terror attacks in Southeast Asia had made the alliance appearing more dominant. The U.S. and Australia too are pressuring some ASEAN countries to buck up on preventing issues like human smuggling and terrorism. The U.S. State Department report, which puts Malaysia in the blacklist, is not something that will make the Malaysian government happy. Similarly, Kuala Lumpur would not like Canberra to sent terror alert signals to international visitors or tourists citing Malaysia and other ASEAN states when an incident take place.

\section{ECONOMIC REGIONALISM AND THE REGIONAL ARCHITECTURE: THE U.S.-AUSTRALIA IMPACT ON SOUTHEAST ASIA}

The search for a proper regional economic architecture in Asia is still an important challenge. Europe has developed a model of supra-national entity in the form of European Union (EU). The North American Free Trade Agreement (NAFTA) has contributed to another type of regional arrangement in North America for trade liberalization. Others like South Asian Association for Regional Cooperation (SAARC), African Union (AU) and so on have attempted to create region wide collaborations. The scenario in East Asia is slightly different. ASEAN 
is the most established regional entity. Rivalry to create a proper identity and region wide entity in East Asia is still there. With the failure of the Uruguay Round of General Agreement on Tariffs and Trade (GATT) in the late 1980s, Australia took the lead to engage some ASEAN members, some major East Asian countries and the US in the economic sphere via APEC. The first APEC ministerial forum was held in Canberra in 1989. ${ }^{19}$ This later became a successful platform for Asia Pacific economic cooperation, which had its first formal summit in Seattle in 1993 under the leadership of President Clinton. Australia is of the opinion that without the U.S., it is difficult to lead the region into economic liberalization.

The failures of the Uruguay Round on trade and tariff discussion in the late 1980s brought about the realization that it was important to start at the regional level. Both the U.S. and Australia were fully aware of the important of Asia as a vital economic entity for future engagement. The idea of APEC did not enjoy full support of all Southeast Asian nations. Malaysia opposed the approach and proposed the East Asia Economic Grouping (EAEG). ${ }^{20}$ Later, Malaysia used ASEAN to promote the idea of an East Asian regionalism of which Australia, New Zealand and the U.S. were excluded. Both Washington and Canberra were not positive of any Asian region wide initiative towards regionalism. Australia's strong interest in Asia is conspicuous given the economic dynamism of the region compared with Europe or North America. Canberra under Keating even went one step further in 1995 by stating that Australia belongs to Asia in order to finding a seat to be included in the Asia-Europe Meeting (ASEM). This is not well liked by some ASEAN members, especially Malaysia. Malaysia under Mahathir had asked ASEAN to initiate the EAEG, which was later adopted as the East Asian Economic Caucus (EAEC) in 1991. Although EAEG has yet to really materialize, numerous dialogues of this nature were carried out under the premise of ASEAN+3, which included Japan, South Korea and China. ${ }^{21}$ Currently this process is activated under the rubric of the EAS of which the U.S. and Australia were included in the EAS after the two signed the TAC as a condition for membership.

The initial exclusion of Australia, New Zealand and the U.S. was a point of major concern in the East Asian regional process for a few years. It highlighted on the vast political and cultural differences 
between Asia and the West. Some have been critical of the East Asian initiatives for having a racial tone. Nonetheless, the East Asian initiative has expanded into another platform called EAS during the Abdullah Ahmad Badawi's administration in Malaysia and had its first summit in 2005 which later expanded its dialogue partners to include U.S., Russia, China, India, Australia and New Zealand.

Today, the EAS is a vital informal forum of special ad hoc value where agendas are not fixed. While progress of this nature, which is inclusive, is praiseworthy, Australia has its own plan of community building for the Asia Pacific region. Contrary to the East Asian community-building project of ASEAN, Australia under Prime Minister Rudd was actively pursuing what it called as the Asia Pacific Community initiative. Both the U.S. and Australia prefers developing the idea of an Asia Pacific community. Canberra believed that the U.S. has underwritten stability of the Asia Pacific region over the half a century and therefore the Asia Pacific community idea can serve as a structure necessary for future stability of the region. The Australian premier at that time suggested that this platform allows for a more inclusive agenda to be discussed involving all forms of security challenges. ${ }^{22}$ This idea did not go well with some ASEAN leaders who believe Australia is a U.S. lackey.

Although Mahathir was no longer in the official scene, Malaysia and several Asian members preferred the East Asian approach towards constructing a regional architecture. The EAS in 2005 had already discussed the idea of an East Asian Community building process. Countries like China had shown support to the ASEAN and Malaysian idea, more than that of Australia's. Canberra's further deliberation on the Asia-Pacific community idea was not seen as highly positive by all the East Asian nations. Some were against the U.S.-Australia agenda to be pushed strongly in Asia, although there can be a few Asian nations may appear neutral to the idea of the Asia-Pacific community. In fact, Rudd's promotion of the Asia-Pacific community was not practical as there are more Latin American and Pacific Island nations that had no clue of this vision.

Australia's bilateral relations with China do have its ups and downs in recent years. With the rise of China and the involvement of India in the EAS process, it is unlikely that Australia and the U.S. 
regional project is likely to resonate strongly or even be accepted without a challenge, even though countries like Japan, South Korea, Taiwan, Mongolia, Philippines, Thailand and Singapore are visible allies of the U.S. While the Asia Pacific Community concept pushed by Prime Minister Rudd few years ago failed, both the U.S. and Australia are active members in trade negotiation and regionalism. The Obama administration's push for the TPPA has full backing from Australia. This is because the TPPA is promoted as a plan to strengthen the APEC trade agreement indirectly of which both Australia and the US are important players in shaping the regional direction from a political economic point of view. At least four ASEAN members, Malaysia, Vietnam, Brunei and Singapore are in the negotiation process. This is also supported by Japan, another strongest U.S. ally. The idea of the TPPA of the Obama administration is basically to move forward the process, because China supported Regional Comprehensive Economic Partnership (RCEP) and Free Trade Area of the Asia Pacific (FTAAP) regimes can be slow in attaining the U.S. and Australia's free trade goals. ASEAN has already successfully concluded the ASEANAustralia-New Zealand Free Trade Area (AANZFTA) a few years ago. The TPPA is another forward moving, legally binding trade regime. Its success is still a long way to come.

\section{CONCLUSION}

Generally, the U.S.-Australia alliance is without doubt an important contribution for regional stability and security. Credit must be also given for the two nations for their contribution in encouraging military exercises and other confidence building initiatives throughout the region. However, there is also a tendency for this alliance to have a strong political and economic influence on the region, which some members in Southeast Asia and Northeast Asia may find it hegemonic. The alliance's big plan to contain China strategically may be seen as a positive move by some, while Beijing feels very uncomfortable about it. While the positive side remains, smaller countries too feel some pressure from the U.S. and Australia since 11 September 2001. The RMSI, PSI and Australia's Maritime Security Zone concepts and initiatives can be viewed negatively in Southeast Asia. Impinging on regional members' sovereignty via these initiatives are regarded negative. In addition, the U.S. and Australia's plan for the regional economic cooperation via APEC and the use of its platform for security 
dialogue too can be seen as redundant and at times down playing the importance of the ARF. In sum, it is no surprise that while the intentions are good, the U.S.-Australia alliance will be viewed as a Western design and one that bears the tendency for a hegemonic and neo-colonial approach towards the region. Although Southeast Asia welcomes the U.S. and Australia to be active in the region, it no longer likes to be told on what ways to move and shape regional architectures. The $21^{\text {st }}$ century will see more of this Asian assertiveness and ASEAN centrality at play using diplomacy and dialogue processes to blunt military might.

\section{NOTES}

1 Discussions with New Zealand military officers who visit annually the Malaysian Armed Forces Staff College (MAFSC) in Kuala Lumpur. I have also attended presentations by New Zealand CSCAP members who were former Government officials and Ambassadors in an informal setting.

2 See White Paper on Foreign Affairs and Trade: Advancing the National Interest, 12 February 2003.

3 Cited by John Graham, "A Security Pact Almost Too Secret for Words," Australia Financial Review, 25 July 1990.

4 David Porter Ball, "Pine Gap's Role Pre-Eminent," The Age, 22 August 1990.

5 Peter Stephens, "Australia to Take Over NW Cape in Seven Years," The Age, 12 October 1990.

6 For a more detailed discussion on the upgrading of the US-Australia alliance, see Jacqueline Rees and Nigel Holloway, "New Australia-US Security Pact Causes Waves," Far Eastern Economic Review, 8 August 1996, p. 18. See also, "Australia-US Bolster Alliance to Promote Regional Stability,” Asian Defence Journal, September 1996, p. 89.

7 For further details see, "Asia Pacific Region and Global Campaign against Terrorism," Asia Pacific Defence Forum, Spring 2002, pp. 4-24.

8 For further details see, "Exercise Tandem Thrust in Australia," Asia Pacific Defence Forum, Winter 2001-2002, pp. 32-41.

9 For a more detailed coverage see, "Australia and US Forces Strengthening Regional Security," Asia Pacific Defence Forum, Fall/Winter, 2005-2006, pp. 2-19.

10 For details on the AUSMIN and the continued relevance of the USAustralia alliance see, William Tow, "Future of Alliances: AUSMIN as a Case 
Study," in Desmond Ball (ed.), Maintaining the Strategic Edge: The Defence of Australia in 2015, Canberra: SDSC, Australian National University, 1991, pp. 259-305

11 "Japan to Join Major US-Australia Military Drill", The Star, 27 May 2015.

12 See Speech by Australian Minister of Foreign Affairs, Tony Street at the ASEAN-Australia Forum in Canberra, 14 April 1981.

13 For further details see, The ASEAN Regional Forum: A Concept Paper, Jakarta: ASEAN Secretariat. 1994.

14 K. S. Balakrishnan, "Maritime Security in Southeast Asia: Malaysia's concerns," in Jatswan S. Sidhu and K. S. Balakrishnan (eds.), The Seas Divide: Geopolitics and Maritime Issues in Southeast Asia, Kuala Lumpur: Institute of Ocean and Earth Sciences (IOES), University of Malaya, 2008, p. 35-46.

15 For further details see, Speech of President Obama Barak Hussein in Cairo University, Egypt, 4 June 2009; and Speech of President Obama Barak Hussein, Moscow, 7 July 2009.

16 Laura Neck, "Middle Powers Once Removed: The Diminished Global Role of Middle Powers and American Grand Strategy," paper presented at the $41^{\text {st }}$ Annual Convention of the International Studies Association (ISA), Los Angeles, 14 March 2000.

17 Frank Ching, "How China Can Make Amends over Rio Tinto," New Straits Times, 20 August 2009.

18 This author served at the international secretariat of CSCAP during 1994-1997. Currently he is one of Malaysia's CSCAP Member Committee. 19 "Australia and APEC in 2007," speech by Australian Prime Minister John Howard at the Asia Society Australasia Centre Annual Dinner, Sydney, 6 June 2007.

20 See Mahathir Mohamad, "Building A New East Asia," Perdana Papers, Kuala Lumpur: Institute of Strategic and International Studies (ISIS), 1997. See also Nordin Sopiee, "EAEC: Fact or Fiction," Opinion Papers, Kuala Lumpur: Institute of Strategic and International Studies (ISIS), 1996.

21 Ibid.

22 See Kevin Rudd, “APc Can Help Make This Asia Pacific Century,” New Straits Times, 18 June 2009. 